\title{
The Role of IL-22 in Viral Infections: Paradigms and Paradoxes
}

\author{
Silvia Gimeno Brias ${ }^{1,2 * t}$, Gabrielle Stack ${ }^{1,2 t}$, Maria A. Stacey ${ }^{1,2}$, Alec J. Redwood ${ }^{3}$ and \\ lan R. Humphreys ${ }^{1,2 *}$
}

${ }^{1}$ Institute of Infection and Immunity, Cardiff University, Cardiff, UK, ${ }^{2}$ Systems Immunity University Research Institute, Cardiff University, Cardiff, UK, ${ }^{3}$ The Institute for Immunology and Infectious Diseases, Murdoch University, Murdoch, WA, Australia

Interleukin-22 (IL-22) is a member of the IL-10 family of cytokines. Hematopoietic cells express IL-22, and this cytokine signals through the heterodimeric IL-22 receptor expressed by non-hematopoietic cells. A growing body of evidence points toward a role for IL-22 in a diverse array of biological functions ranging from cellular proliferation, tissue protection and regeneration, and inflammation. In recent years, the role that IL-22 plays in antiviral immune responses has been examined in a number of infection models.

\section{OPEN ACCESS}

Edited by:

Michael Harrison Hsieh,

Children's National Health System,

Reviewed by:

Mirko Trilling,

University Duisburg-Essen, Germany Jared Honeycutt,

Stanford University, USA

${ }^{*}$ Correspondence:

Silvia Gimeno Brias gimenobriass@cardiff.ac.uk; Ian R. Humphreys

humphreysir@cf.ac.uk

+Silvia Gimeno Brias and Gabrielle Stack contributed equally.

Specialty section: This article was submitted to Microbial Immunology, a section of the journal Frontiers in Immunology

Received: 15 April 2016 Accepted: 17 May 2016

Published: 30 May 2016

Citation:

Gimeno Brias S, Stack G,

Stacey MA, Redwood AJ and Humphreys IR (2016) The Role of IL-22 in Viral Infections: Paradigms and Paradoxes.

Front. Immunol. 7:211. doi: 10.3389/fimmu.2016.00211
Herein, we assess our current understanding of how IL-22 determines the outcome of viral infections and define common mechanisms that are evident from, sometimes paradoxical, findings derived from these studies. Finally, we discuss the potential therapeutic utility of IL-22 manipulation in the treatment and prevention of viral infections and associated pathologies.

Keywords: viruses, cytokines, pathology, immune system diseases, cytomegalovirus

\section{THE IL-22-IL-22R PATHWAY}

Interleukin-22 (IL-22) is a member of the IL-10 family of cytokines that was originally identified as an IL-9-inducible gene produced by mouse T cells $(1,2)$. Since its discovery, IL-22 expression by a number of immune cell subsets has been detected, including activated natural killer (NK) cells, NKT cells, neutrophils, $\gamma \delta$ T cells, innate lymphoid cells (ILCs), and CD8 ${ }^{+} \mathrm{T}$ cells (3-9). In addition, IL-22 is expressed by CD4 $4^{+} \mathrm{T}$ cells of the $\mathrm{T}_{\mathrm{H}} 17$ (4) and $\mathrm{T}_{\mathrm{H}} 1$ lineage (10). Moreover, $\mathrm{T}_{\mathrm{H}} 22$, a CD4 ${ }^{+}$ $\mathrm{T}$ cell subset distinct from $\mathrm{T}_{\mathrm{H}} 1$ and $\mathrm{T}_{\mathrm{H}} 17$ cells, has been described (11). $\mathrm{T}_{\mathrm{H}} 22$ cells produce IL-22 independently of IFN- $\gamma$ and IL-17 production and can be distinguished from $\mathrm{T}_{\mathrm{H}} 17$ cells by the expression of CCR10 (11-14). Given the diversity of the innate and adaptive cells that can produce IL-22 and plasticity among T helper cell subsets, there have been significant efforts to identify common regulators of leukocyte IL-22 production. Subsequently, IL-23 and aryl hydrocarbon receptor (AhR) have emerged as key inducers of IL-22 production in NK cells, ILCs, CD4 $4^{+} \mathrm{T}$ cells, and $\gamma \delta \mathrm{T}$ cells $(6,15-23)$.

The IL-22 receptor (IL-22R) is a heterodimer that is composed of IL-22R $\alpha$ and IL-10R $\beta$ (24). IL-22R $\alpha$ also forms a complex with IL-20R $\beta$, which is an alternative receptor complex for IL-20 and IL-24, and is thought to induce signals and biological effects similar to those elicited by the IL-22 receptor complex $(25,26)$. IL-10R $\beta$ is ubiquitously expressed by most cell types, whereas the expression of IL-22R $\alpha$, which ultimately determines the target sites of IL-22, is restricted to non-hematopoietic cells, predominantly epithelial cells of the skin, lung, small intestine, kidney, colon, liver, and pancreas $(24,27)$. IL-22 binding to the dimeric IL-22R triggers phosphorylation and subsequent activation of the kinases Jak1 and Tyk2, which leads to the activation of the transcription factor STAT3, and also STAT5 and STAT1. Furthermore, MAP kinase and p38 pathways are involved in downstream IL-22R signaling $(27,28)$. In addition, a soluble, secreted single-chained IL-22-binding receptor, IL-22 
binding protein (IL-22BP), can bind IL-22 with stronger affinity than membrane-bound IL-22R, thus antagonizing IL-22 signaling (29-31). IL-22BP expression has been reported in multiple tissues, including the spleen, lung, skin, and female reproductive system $(29,31)$, and by several hematopoietic cells including immature dendritic cells (DCs) and eosinophils (32-34). IL-22BP is highly expressed in steady-state conditions and downregulated in response to inflammasome activation during tissue damage, coinciding with IL-22 expression, thereby reducing the suppression that IL-22BP exerts on IL-22 signaling (34).

The IL-22-IL-22R pathway exerts a broad array of biological effects in different systems. Experimental models have shown that IL-22 prevents tissue destruction and mediates regeneration of damaged tissue by inducing expression of genes regulating proliferation, survival, and wound healing, ameliorating tissue damage in colitis $(35,36)$, hepatitis $(37,38)$, and lung fibrosis $(39)$. Paradoxically, in certain contexts, IL-22 can promote inflammation. For example, overexpression of IL-22 has been associated with psoriasis $(5,40,41)$, inflammatory bowel disease (42), and arthritis $(43,44)$.

The role of IL-22 in tumor development has been reported in several types of cancers, including gastric, lung, colon, hepatocellular, and pancreatic carcinoma, where studies have shown upregulation of IL-22 by tumor-infiltrating lymphocytes in the tumor microenvironment, in addition to the expression of its receptor on cancerous cells (45-49). In hepatocellular carcinoma, pancreatic cancer, and colorectal cancer, IL-22 expression positively correlated with tumor growth, metastasis, and tumor stages $(46,47,50,51)$. This was associated with STAT3 phosphorylation and upregulation of downstream genes Cyclin D (proliferation), Bcl-xl (cell survival), and VEGF (metastasis) $(46,47)$. Furthermore, recent studies using mouse models of colon cancer have shown that IL-22 produced by $\mathrm{CD} 4^{+} \mathrm{T}$ cells acts upon cancer cells to activate STAT3 and promote the expression of the histone 3 lysine 79 (H3K79) methyltransferase DOT1L, which induces key cancer stem cell genes that contribute to tumor progression $(34,52,53)$. Additionally, in colorectal cancer and lung cancer cells, IL-22 contributes to resistance to chemotherapy by activating STAT3 and subsequently upregulating antiapoptotic genes $(48,54)$.

Interleukin-22 plays an important protective role in host defense responses during bacterial infections. For example, IL-22R signaling increases the production of antibacterial peptides and proteins $(27,40)$, acute-phase proteins $(2,42)$, mucins $(35,55)$, and increases the production of neutrophilic granulocyte-attracting chemokines [as reviewed in Ref. (56)].

The impact of IL-22R signaling extends beyond pathogenic bacterial infections. IL-22 also influences host resistance to bacterial pathogens through regulation of the interface between epithelial cells and microbiota. Germ-free mice exhibit reduced numbers of intestinal ILCs that express IL-22 (57). Tryptophan metabolites produced by intestinal microbiota activate the AhR in ILC3s to produce IL-22, contributing to the containment of commensal bacteria, limiting inflammation, and preserving gut immune homeostasis $(58,59)$. In return, IL-22 regulates the gene Fut 2 that encodes the enzyme $\alpha 1,2$-fucosyltransferase that catalyzes the addition of fucose residues to glycoproteins on epithelial cells. This influences the nutrient environment of the microbiota and thus impacts on the diversity and composition of the gut flora and subsequently prevents colonization of pathogens (60-62). Indeed, defective fucosylation has been associated with increased susceptibility to candidiasis (63) and the opportunistic pathogen Enterococcus faecalis (61). However, IL-22 favors Salmonella infection by inducing antimicrobial proteins that sequester metal ions allowing Salmonella, which can overcome metal starvation, to outcompete other commensals (64). Thus, context is critical in determining antimicrobial or pathogenic function of IL-22.

Interleukin-22 also contributes to protective immunity in the early stages of fungal infection with Candida albicans $(65,66)$, Aspergillus fumigatus (67), and Rhizomucor pusilluscan (68). In candidiasis, IL-22 is produced by innate (DCs and CD3 ${ }^{-} \mathrm{NKp} 46^{+}$ cells) and adaptive ( $\mathrm{T}_{\mathrm{H}} 17$ and memory C. albicans-specific IL- $22^{+} \mathrm{CD}^{+}$cells) immune cells $(65,66)$, with IL-23 regulating IL-22 production by $\mathrm{T}_{\mathrm{H}} 17$ cells (66). IL-22 targets epithelial cells to release S100A8 and S10A9 peptides that participate in antifungal protection (66). In $A$. fumigatus infections, $\beta$-glucan recognition via Dectin-1 as well as IL-23 induces lung IL-22 production for antifungal protection (67). Thus, IL-22 orchestrates immune responses to bacterial and fungal pathogens directly, and through the regulation of the intestinal microbiota.

\section{IL-22 PRODUCTION DURING VIRAL INFECTIONS}

Although the role that IL-22 plays in bacterial and fungal infections is reasonably well-defined, a picture of how IL-22 functions in viral infections is still being constructed. Experiments using IL-22 fate-tracker mice have demonstrated IL- $22^{+}$cells in this model are predominantly ILCs, $\gamma \delta \mathrm{T}$ cells, and $\mathrm{CD} 4^{+} \mathrm{T}$ cells in the gut, skin, and lung under homeostatic conditions (69). IL-22 reporter mice also highlighted the lamina propria as a rich source of IL-22 $2^{+} \mathrm{T}$ cells in steady state (70). However, it is clear that upon viral exposure, IL-22 is produced by a number of leukocytes in response to a broad array of virus infections. For example, pulmonary NK cells produce IL-22 in response to influenza infection (71). IL-23 stimulates the production of IL-22 during bacterial infections $(22,72)$, and IL-22 expression by pulmonary NK cells is induced by IL-23 in vitro (71). Furthermore, influenza induces IL-22 expression by invariant NK T cells in manner dependent upon triggering of the viral RNA sensors TLR7 and RIG-I in DCs and subsequent production of IL-1 $\beta$ and IL-23 (73).

During acute murine cytomegalovirus (MCMV) infection, T cells, NK T cells, and NK cells produce IL-22 (74). NK cells, which restrict MCMV replication in the spleen, liver, and lung $(75,76)$, produce IL-22 in response to MCMV infection in the liver and lung but not spleen, demonstrating that IL-22 induction in systemic viral infection is organ-specific (Figure 1A). Similarly, significant IL-22 expression by intrahepatic but not peripheral NK T cells, $\gamma \delta$ T cells, and NK cells in hepatitis B virus (HBV)-infected individuals has been demonstrated (77). IL-22-producing NK cells within the peripheral sites of MCMV infection are phenotypically indicative of classical NK cells (Figure 1B). In this infection model, NK cells are stimulated through the activating receptor $\mathrm{Ly} 49 \mathrm{H}$, following recognition of the MCMV m157 protein (78). However, despite expressing significant levels of Ly49H (Figure 1B), mice 

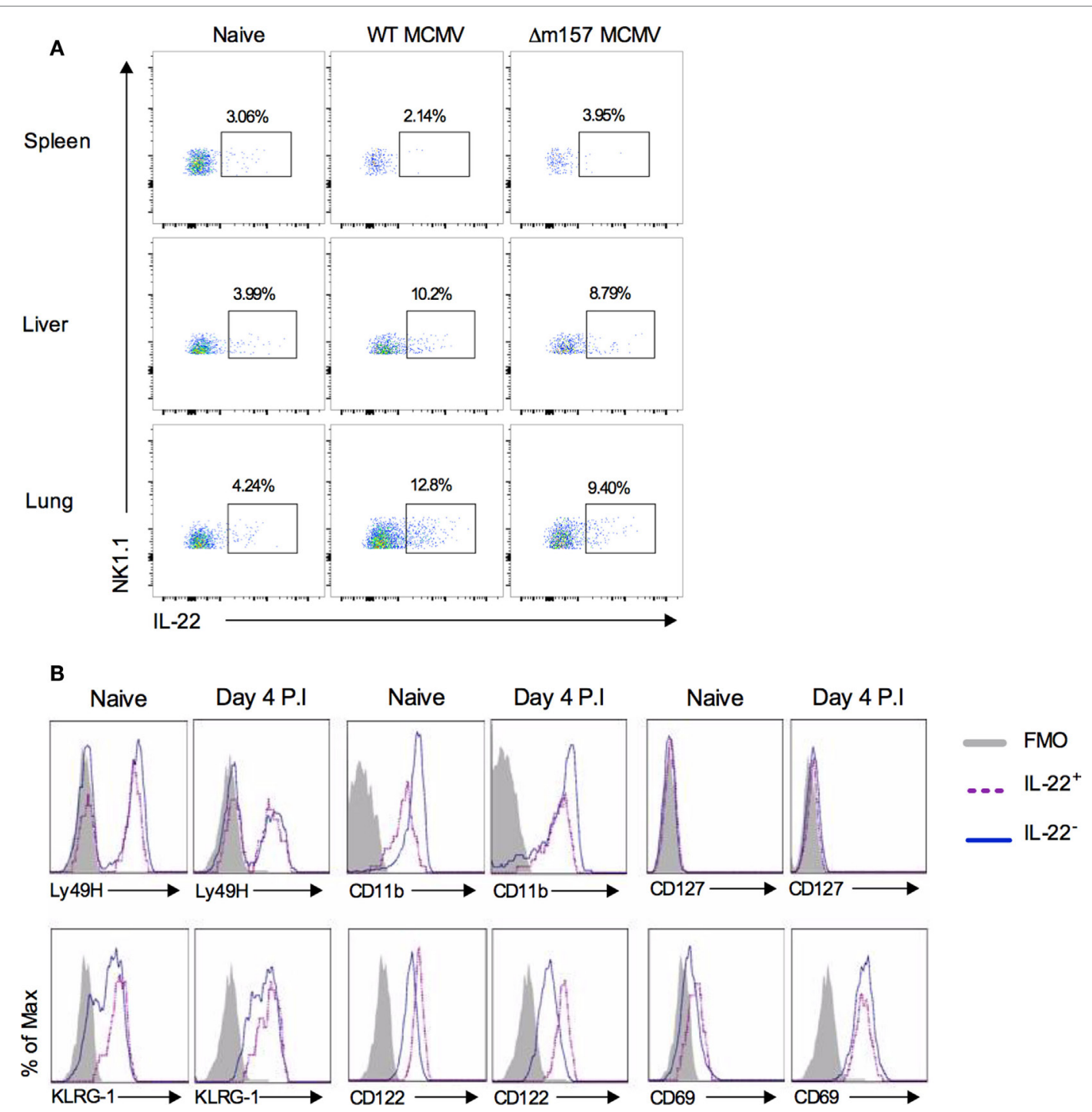

FIGURE 1 IL-22 production by NK cells during murine cytomegalovirus infection. (A) C57BL/6 mice were infected or not with $5 \times 10^{5}$ pfu of wild-type (pARK25) or m157 knock out ( $\triangle \mathrm{m} 157) \mathrm{K} 181$ strain MCMV. At day 4 postinfection, spleen, liver, and lung were harvested, leukocytes isolated, and stained against NK1.1, CD49b, CD3, NKp46, and IL-22. Representative plots of IL-22 versus NK1.1 expression by NK1.1 $1^{+}$CD49b+NKp46 ${ }^{+} \mathrm{CD}^{-}$cells are shown. Results represent three mice/group. (B) C57BL/6 mice were infected or not with salivary gland-propagated Smith strain MCMV $\left(5 \times 10^{4}\right.$ pfu). Surface marker expression by pulmonary NK1.1 $1^{+} \mathrm{LL}-22^{+}$and NK1.1 $1^{+} \mathrm{LL}-22^{-}$cells was assessed by flow cytometry. Representative overlay histograms of pulmonary NK1.1 $1^{+} \mathrm{LL}-22^{+}$(dashed purple line) and $\mathrm{NK} 1.1^{+} \mathrm{IL}-22^{-}$(solid blue line) at day 4 postinfection are shown (shaded histogram $=\mathrm{FMO}$ control from infected mice). Results are representative of four mice per group.

challenged with m157-deficient ( $\Delta$ m157) MCMV induced comparable pulmonary and hepatic IL-22 ${ }^{+} \mathrm{NK}$ cell responses to those in WT MCMV infection (Figure 1A). $\Delta \mathrm{m} 157$ and WT MCMV infections also induced comparable early contraction of NK cell responses in the initial phase of infection (76) as indicated by a comparable reduction in NK1.1 $1^{+}$cells, as compared to naive mice (Figure 1A). Collectively, experimental data point toward an important function of IL-22 production by NK cells during certain viral infections and suggest a role for cytokines, but not activation receptor ligation in inducing NK cell expression of IL-22.

$\mathrm{T}$ cells also produce IL-22 in response to some viruses. Activated $\mathrm{T}$ cells isolated from blood of healthy individuals that are repeatedly exposed to human immunodeficiency virus (HIV-1) overproduce IL-22 (79). IL-22-expressing $\mathrm{CD}^{+}$and $\mathrm{CD}^{+} \mathrm{T}$ cells reactive to HIV Gag proteins in uninfected partners of $\mathrm{HIV}^{+}$individuals have been identified (80). $\mathrm{T}$ cells isolated from liver and peripheral blood of $\mathrm{HBV}$-infected individuals also express IL-22, as do $\mathrm{CD}_{161} 1^{+} \mathrm{CD} 4^{+}$and $\mathrm{CD} 8^{+} \mathrm{T}$ cells enriched in liver of hepatitis $\mathrm{C}$ virus (HCV)-infected patients $(81,82)$. In intestinal rotavirus infection, ILCs are also implicated as a significant source of IL-22 $(83,84)$, in accordance with the established role of ILCs as IL-22 producers in mucosal tissue [as reviewed in Ref. (85)]. Thus, innate and adaptive antiviral cellular responses can produce IL-22 following viral exposure. 


\section{IL-22 AND PROTECTION FROM VIRAL INFECTION AND ASSOCIATED PATHOLOGIES}

A number of studies have identified or implied an antiviral function for IL-22. IL-22 exerts critical control of rotavirus infection $(83,84)$ and can cooperate with IL-18 $(83)$ or with IFN- $\lambda(84)$. In the case of cooperation with IFN- $\lambda$, IL-22 augments interferonstimulated gene (ISG) expression by intestinal epithelial cells (84). In contrast to the dominant induction of STAT3 by IL-22R signaling, IL-22 augmentation of IFN- $\lambda$ ISG expression in response to rotavirus infection is dependent upon STAT1 activation (84).

Interleukin-22 receptor signaling can induce the expression of chemokines thereby orchestrating recruitment of immune cell subsets to sites of infection. In MCMV infection, IL-22 has a protective role in the lung and liver, where it recruits antiviral neutrophils via induction of CXCL1 (74). In contrast, IL-22 does not influence MCMV replication or neutrophil recruitment in the spleen, suggesting that the influence of IL-22 in a viral infection may depend upon the tissue microenvironment and/ or IL-22-responsive cells (74). Chemokine-inducing properties of IL-22 may also be important in the induction of virus-specific antibody responses. Direct cannulation of replication-deficient adenovirus into murine salivary glands induces formation of tertiary lymphoid organs and autoantibody production. This process is dependent upon IL-22 and is associated with IL-22-mediated induction of CXCL13 and CXCL12 (86). Although studies from our own lab using the MCMV infection model demonstrate no protective function of IL-22 in orchestrating T cell-dependent control of virus replication within the salivary glands (unpublished data), it is conceivable that IL-22 may afford mucosal protection from viral infections through the induction of local $\mathrm{T}: \mathrm{B}$ cell aggregates and virus-specific antibody generation.

Current evidence suggests that IL-22 may exhibit antiviral activity in HIV-infected individuals. IL-22 stimulates production of acute-phase serum amyloid A, which can induce phosphorylation and downregulation of CCR5 expression on immature DCs, thus decreasing susceptibility to HIV-1 infection (79). Also, high systemic levels of IL-22 in Indian individuals infected with HIV-1 subtype $\mathrm{C}$ is associated with low viral replication in vitro, which was attributed to IL-22 interacting with IL-10 and C-reactive protein (87). Furthermore, loss of IL-22-producing $\mathrm{CD}^{+} \mathrm{T}$ cells during chronic HIV infection has been associated with increased damage to the gut epithelium and microbial translocation (88), although IL-22-producing ILCs may compensate for the loss of $\mathrm{IL}_{-22^{+}} \mathrm{CD}^{+} \mathrm{T}$ cells and maintain mucosal integrity (89). Irrespective of the cellular source of IL-22, systemic IL-22 levels negatively correlate with plasmatic lipopolysaccharide, an indicator of microbial translocation from the gut (87). Thus, IL-22R signaling may also be beneficial in HIV-infected individuals by maintaining barrier function.

In a number of viral infections, IL-22 signaling in the liver provides protection against virus-induced pathology without actually influencing virus replication. IL-22 produced by $\mathrm{CD} 4^{+} \mathrm{T}$ cells is cytoprotective during lymphocytic choriomeningitis virus infection in mice, where it reduces the development of hepatitis (90).
In accordance, during HBV infection, IL-22-expressing cells co-localize with liver progenitor cells, and IL-22 promotes STAT3dependent liver stem/progenitor cells (LPC) proliferation (91). IL-22 also restricts hepatic damage and inflammation induced by dengue virus, a phenotype associated with the suppression of the IL-17R pathway (92). IL-22 is also important for the regeneration of tracheal and lung epithelial cells after influenza infection, preventing lung pathology and secondary bacterial infection (93-95). IL-22 $2^{-/}$mice exhibit impaired regeneration of tracheal epithelium and exacerbated weight loss after clearance of influenza infection; a phenotype rescued by transfer of IL-22-proficient but not deficient NK cells (93). Finally, IL-22 restricts myocardial fibrosis induced by coxsackie virus infection (96), demonstrating the importance for IL-22 restriction of tissue damage and pathology that occurs as a consequence of viral infections.

\section{IL-22 AS A CONTRIBUTORY FACTOR IN VIRAL PATHOGENESIS}

In certain contexts, IL-22 is harmful to virus-infected hosts. As observed in MCMV infection, IL-22 promotes recruitment of neutrophils in response to West Nile virus (WNV) infection. However, in contrast to the antiviral role for neutrophils in MCMV infection, IL-22-induced neutrophil responses in the central nervous system (CNS) during WNV infection lead to exacerbated pathology and mortality (97). Rather than exhibiting antiviral activity, here neutrophils act as vehicles for WNV dissemination into the CNS, thus aiding the establishment of infection and subsequent inflammation within this site (97).

Intriguingly and in contrast to studies describing a cytoprotective role for IL-22 in tissue repair following HBV infection (91), in a murine model of HBV infection IL-22 supported virus-driven inflammation and consequential liver damage without affecting virus replication. In this model, IL-22 promoted chemokine expression and the recruitment of inflammatory leukocytes (98). Similarly, IL-22 promotes HBV-induced pathology through chemokine-mediated recruitment of $\mathrm{T}_{\mathrm{H}} 17$ cells (77), thus demonstrating that IL-22 can mediate paradoxical tissue-protective and proinflammatory functions in response to the same viral pathogen. HBVs and HCVs are implicated in the development of certain cancers [reviewed in Ref. (99)]. IL-22 protein levels in serum of patients with HBV-and HCV-associated hepatocellular carcinomas is an indicator of poor prognosis $(100,101)$, implying that virus-induced IL-22 may promote tumor development associated with these infections. Clearly, the possible role that IL-22 plays in the development of other virus-associated cancers (e.g., human papilloma virus-induced cervical cancer) requires a better understanding.

\section{IS IL-22 A POTENTIALLY USEFUL THERAPEUTIC TARGET IN VIRAL INFECTION?}

Overall, current data suggest that IL-22 may have an important role in a number of virus infections (as summarized in Figures 2A,B). 
A

\begin{tabular}{|c|c|c|c|c|c|}
\hline Virus & $\begin{array}{l}\text { Primary site of } \\
\text { viral replication }\end{array}$ & IL-22 source & $\begin{array}{l}\text { Protectivel } \\
\text { Pathological }\end{array}$ & Mechanism & Reference \\
\hline MCMV & $\begin{array}{l}\text { Epithelial, } \\
\text { endothelial and } \\
\text { myeloid cells }\end{array}$ & $\begin{array}{l}\text { NK, NKT and T } \\
\text { cells }\end{array}$ & Protective & Recruits antiviral neutrophils & (74) \\
\hline HIV-1 & $\begin{array}{l}\mathrm{CD}^{+} \mathrm{T} \text { cells and } \\
\text { macrophages }\end{array}$ & $\begin{array}{l}\text { T cells/ } \\
\text { Not defined }\end{array}$ & Protective? & $\begin{array}{l}\text { Possible mechanism: } \\
\text { Phosphorylation and } \\
\text { downregulation of CCR5. } \\
\text { Acts in consort with IL-10 and C- } \\
\text { reactive protein to reduce virus } \\
\text { replication }\end{array}$ & $(79,87)$ \\
\hline Rotavirus & $\begin{array}{l}\text { Epithelial cells of } \\
\text { the small intestine }\end{array}$ & ILCs & Protective & $\begin{array}{l}\text { Limits virus replication by } \\
\text { augmenting ISG expression }\end{array}$ & (84) \\
\hline LCMV & Dendritic cells & $\mathrm{CD}^{+} \mathrm{T}$ cells & Protective & Restricts hepatitis & (90) \\
\hline Hepatitis B & Hepatocytes & T cells & Protective & $\begin{array}{l}\text { Proliferation of progenitor cells, } \\
\text { reduces pathology }\end{array}$ & (91) \\
\hline $\begin{array}{l}\text { Dengue } \\
\text { virus }\end{array}$ & $\begin{array}{l}\text { Macrophages and } \\
\text { monocytes }\end{array}$ & NK cells & Protective & $\begin{array}{l}\text { Reduces neutrophil accumulation } \\
\text { and the production of } \\
\text { proinflammatory cytokines }\end{array}$ & (92) \\
\hline Influenza & $\begin{array}{l}\text { Epithelial cells of } \\
\text { the respiratory tract }\end{array}$ & NK and T cells & Protective & $\begin{array}{l}\text { Promotes epithelial cell } \\
\text { regeneration }\end{array}$ & $(93,94,95)$ \\
\hline WNV & $\begin{array}{l}\text { Monocytes, } \\
\text { macrophages, DCs, } \\
\text { endothelial cells } \\
\text { and neurons }\end{array}$ & Not defined & Pathological & Recruits neutrophils to CNS & (97) \\
\hline
\end{tabular}

B

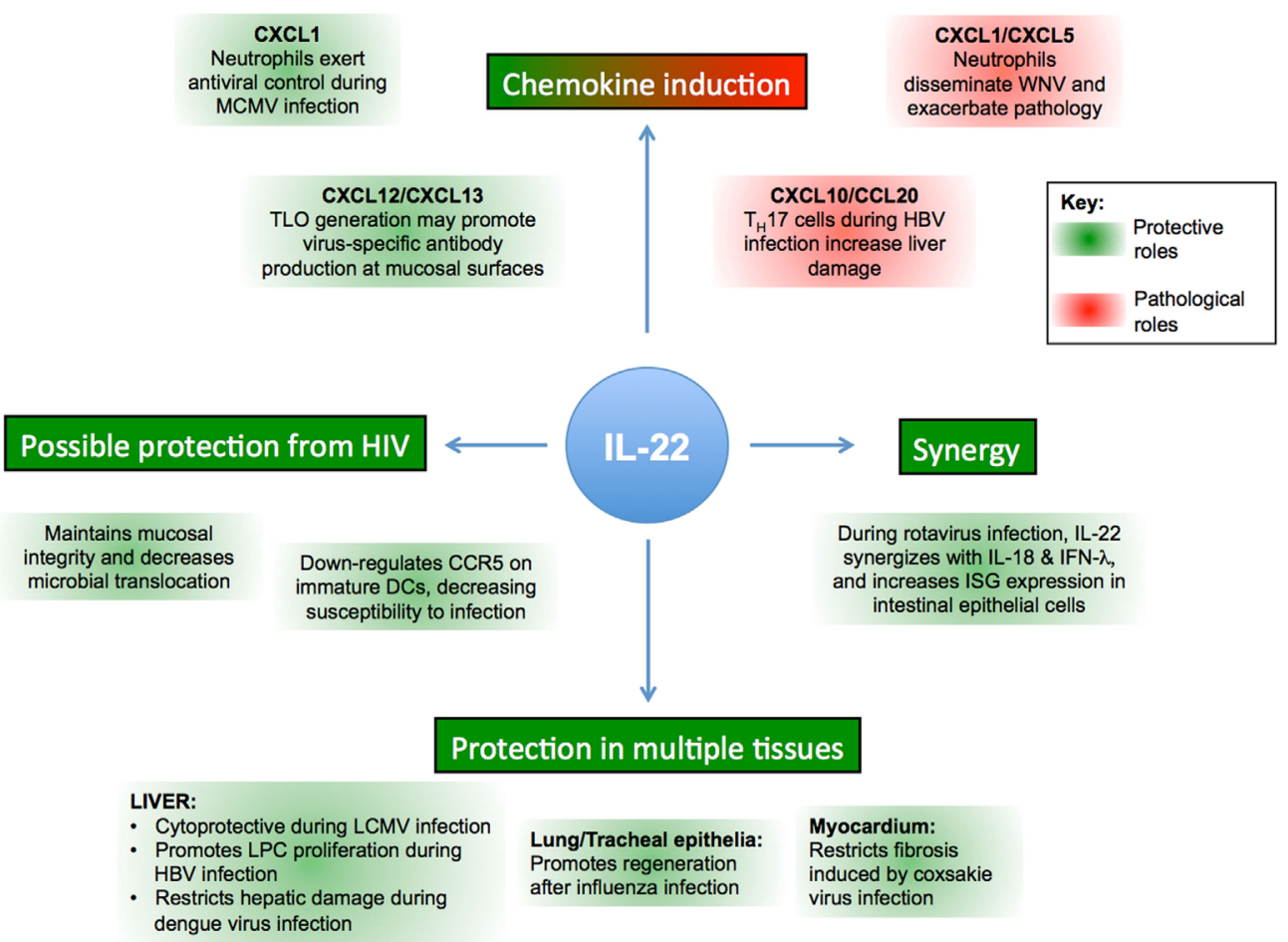

FIGURE 2 | IL-22 in viral infections. (A) Summary of impact of IL-22 in experimental viral infections. (B) Schematic representation of protective (green) and pathological (red) functions of IL-22 in viral infections.

However, the broad and sometimes paradoxical protective and proinflammatory functions exhibited by IL-22 highlights the complex nature of this cytokine. Thus, does IL-22 represent a useful therapeutic target for clinical intervention strategies for viral infections, and can we predict how IL-22 will influence an immune response induced by a particular virus? 
Certain paradigms emerge from published data that may guide future studies that aim to answer these questions. First, it is clear from numerous experimental models that an important function of IL-22 is to induce chemokine expression. The differing roles for neutrophils in MCMV and WNV infections highlight the importance of using in vivo infection models to understand what chemokines are induced by IL-22 in response to a particular viral infection and to define the role that IL-22recruited cells play in antiviral immune responses in infected tissues. Studies of rotavirus infection highlight the importance of IL-22 synergy with other cytokine pathways $(83,84)$. The timing and context in which IL-22 is produced may greatly influence the impact that this cytokine has on antiviral immune responses.

Understanding the cytokine signature induced by a virus in a particular tissue in addition to defining signaling pathways induced by combinations of cytokines that include IL-22 will likely yield useful information required for predicting the impact of IL-22 in a particular viral infection. Indeed, pathological consequences of IL-22R signaling in HBV infection appear to be intrinsically related to virus-induced IL-17 production $(77,98)$. Furthermore, IL-22 is implicated in fatal alphavirus encephalomyelitis when unregulated $\mathrm{T}_{\mathrm{H}} 17$ development occurs in the absence of IL-10-mediated suppression (102). Although IL-17 and IL-22 mediate synergistic protective immunity in bacterial infection $(55,103,104)$, the combination of these cytokines in viral infections may have pathological consequences.

Should a more defined role for IL-22 during viral infections be elucidated, manipulating the production/availability of IL-22 could prove therapeutically beneficial in treatment and, possibly, prevention of viral-associated disease. For example, administration of IL-22 may accelerate patient recovery from influenza or cytomegalovirus infections by improving lung barrier function or innate antiviral immune responses, respectively. Conversely, IL-22 neutralization could ameliorate virus-induced inflammation in certain infections. However, alteration of IL-22 signaling could have undesired consequences. Blocking the action of IL-22 could increase host susceptibility to bacterial and fungal infection. Conversely, given the protumoral role for $\mathrm{T}$ cell-expressed IL-22 in cancer $(45,46,49,52,53,68)$, prolonged therapeutic administration IL-22 has the risk of promoting tumor development. Furthermore, more information regarding the mechanisms that regulate IL-22 production by virus-specific T cells is essential

\section{REFERENCES}

1. Dumoutier L, Louahed J, Renauld JC. Cloning and characterization of IL-10-related T cell-derived inducible factor (IL-TIF), a novel cytokine structurally related to IL-10 and inducible by IL-9. J Immunol (2000) 164:1814-9. doi:10.4049/jimmunol.164.4.1814

2. Dumoutier L, Van Roost E, Colau D, Renauld JC. Human interleukin-10-related $\mathrm{T}$ cell-derived inducible factor: molecular cloning and functional characterization as an hepatocyte-stimulating factor. Proc Natl Acad Sci U S A (2000) 97:10144-9. doi:10.1073/pnas.170291697

3. Wolk K, Kunz S, Asadullah K, Sabat R. Cutting edge: immune cells as sources and targets of the IL-10 family members? J Immunol (2002) 168:5397-402. doi:10.4049/jimmunol.168.11.5397 before IL-22-inducing vaccines and other therapies are considered for clinical utility.

Given the established role of IL-22 in bacterial infections, the interaction between viruses and bacteria should also be considered when manipulating IL-22 in virus-infected individuals. Antibiotic treatment impairs the induction of protective immunity during influenza infection (105), suggesting that IL-22 modulation of the microbiota may impact on patient outcome. Furthermore, bacterial coinfections cause pathogenesis in individuals infected with viruses such as influenza (106). Thus, diagnosis of bacterial coinfections in patients and understanding how IL-22 impacts on these bacteria will be an important consideration in IL-22-based clinical intervention strategies.

Thus, overall, although IL-22 is clearly an important cytokine in antiviral immune responses, more information regarding the context-dependent nature of IL-22 regulation and function is required before manipulation of this cytokine can be considered in the treatment of virus-infected individuals.

\section{ETHICS STATEMENT}

All animal research was performed under the UK Home Office-approved Project License PPL 30/2969, awarded to Ian Humphreys.

\section{AUTHOR CONTRIBUTIONS}

SGB and MAS performed experiments. SGB, MAS and IRH interpreted the data. AJR generated key reagents and edited the manuscript. SGB, GS, MAS and IRH wrote the manuscript.

\section{ACKNOWLEDGMENTS}

The authors wish to thank Gareth Jones for critical reading of this manuscript.

\section{FUNDING}

This work was supported by a Wellcome Trust Senior Research Fellowship in Basic Biomedical Sciences (WT098026) awarded to IH. AR was supported by the National Health and Medical Research Council and the WA Department of Health FutureHealth WA Merit Award program (2013-14). SB was funded by an MRC Doctoral Training Grant.

4. Chung Y, Yang X, Chang SH, Ma L, Tian Q, Dong C. Expression and regulation of IL-22 in the IL-17-producing CD4+ T lymphocytes. Cell Res (2006) 16:902-7. doi:10.1038/sj.cr.7310106

5. Zheng Y, Danilenko DM, Valdez P, Kasman I, Eastham-Anderson J, Wu J, et al. Interleukin-22, a TH17 cytokine, mediates IL-23-induced dermal inflammation and acanthosis. Nature (2007) 445:648-51. doi:10.1038/ nature 05505

6. Basu R, O'Quinn DB, Silberger DJ, Schoeb TR, Fouser L, Ouyang W, et al. Th22 cells are an important source of IL-22 for host protection against enteropathogenic bacteria. Immunity (2012) 37:1061-75. doi:10.1016/j. immuni.2012.08.024

7. Zindl CL, Lai JF, Lee YK, Maynard CL, Harbour SN, Ouyang W, et al. IL22-producing neutrophils contribute to antimicrobial defense and restitution 
of colonic epithelial integrity during colitis. Proc Natl Acad Sci U S A (2013) 110:12768-73. doi:10.1073/pnas.1300318110

8. Goto M, Murakawa M, Kadoshima-Yamaoka K, Tanaka Y, Nagahira K, Fukuda Y, et al. Murine NKT cells produce Th17 cytokine interleukin-22. Cell Immunol (2009) 254:81-4. doi:10.1016/j.cellimm.2008.10.002

9. Moreira-Teixeira L, Resende M, Coffre M, Devergne O, Herbeuval JP, Hermine O, et al. Proinflammatory environment dictates the IL-17-producing capacity of human invariant NKT cells. J Immunol (2011) 186:5758-65. doi:10.4049/jimmunol.1003043

10. Volpe E, Touzot M, Servant N, Marloie-Provost MA, Hupe P, Barillot E, et al. Multiparametric analysis of cytokine-driven human Th17 differentiation reveals a differential regulation of IL-17 and IL-22 production. Blood (2009) 114:3610-4. doi:10.1182/blood-2009-05-223768

11. Eyerich S, Eyerich K, Pennino D, Carbone T, Nasorri F, Pallotta S, et al. Th22 cells represent a distinct human $\mathrm{T}$ cell subset involved in epidermal immunity and remodeling. J Clin Invest (2009) 119:3573-85. doi:10.1172/JCI40202

12. Trifari S, Kaplan CD, Tran EH, Crellin NK, Spits H. Identification of a human helper $\mathrm{T}$ cell population that has abundant production of interleukin 22 and is distinct from Th-17, Th1 and Th2 cells. Nat Immunol (2009) 10:864-71. doi:10.1038/ni.1770

13. Duhen T, Geiger R, Jarrossay D, Lanzavecchia A, Sallusto F. Production of interleukin 22 but not interleukin 17 by a subset of human skin-homing memory T cells. Nat Immunol (2009) 10:857-63. doi:10.1038/ni.1767

14. de Jong A, Peña-Cruz V, Cheng TY, Clark RA, Van Rhijn I, Moody DB. CDla-autoreactive T cells are a normal component of the human $\alpha \beta$ T cell repertoire. Nat Immunol (2010) 11:1102-9. doi:10.1038/ni.1956

15. Cella M, Fuchs A, Vermi W, Facchetti F, Otero K, Lennerz JKM, et al. A human natural killer cell subset provides an innate source of IL-22 for mucosal immunity. Nature (2009) 457:722-5. doi:10.1038/nature07537

16. Crellin NK, Trifari S, Kaplan CD, Satoh-Takayama N, Di Santo JP, Spits H. Regulation of cytokine secretion in human CD127+ LTi-like innate lymphoid cells by toll-like receptor 2. Immunity (2010) 33:752-64. doi:10.1016/j. immuni.2010.10.012

17. Geremia A, Arancibia-Cárcamo CV, Fleming MPP, Rust N, Singh B, Mortensen NJ, et al. IL-23-responsive innate lymphoid cells are increased in inflammatory bowel disease. J Exp Med (2011) 208:1127-33. doi:10.1084/ jem.20101712

18. Qiu J, Heller JJ, Guo X, Chen ZE, Fish K, Fu Y-X, et al. The aryl hydrocarbon receptor regulates gut immunity through modulation of innate lymphoid cells. Immunity (2012) 36:92-104. doi:10.1016/j.immuni.2011.11.011

19. Veldhoen M, Hirota K, Christensen J, O’Garra A, Stockinger B. Natural agonists for aryl hydrocarbon receptor in culture medium are essential for optimal differentiation of Th17 T cells. JExp Med (2009) 206:43-9. doi:10.1084/jem.20081438

20. Veldhoen M, Hirota K, Westendorf AM, Buer J, Dumoutier L, Renauld JC, et al. The aryl hydrocarbon receptor links TH17-cell-mediated autoimmunity to environmental toxins. Nature (2008) 453:106-9. doi:10.1038/nature06881

21. Ramirez JM, Brembilla NC, Sorg O, Chicheportiche R, Matthes T, Dayer JM, et al. Activation of the aryl hydrocarbon receptor reveals distinct requirements for IL-22 and IL-17 production by human Thelper cells. Eur I Immunol (2010) 40:2450-9. doi:10.1002/eji.201040461

22. Muñoz M, Heimesaat MM, Danker K, Struck D, Lohmann U, Plickert R, et al. Interleukin (IL)-23 mediates Toxoplasma gondii-induced immunopathology in the gut via matrixmetalloproteinase-2 and IL-22 but independent of IL-17. J Exp Med (2009) 206:3047-59. doi:10.1084/jem.20090900

23. Martin B, Hirota K, Cua DJ, Stockinger B, Veldhoen M. Interleukin-17producing $\gamma \delta \mathrm{T}$ cells selectively expand in response to pathogen products and environmental signals. Immunity (2009) 31:321-30. doi:10.1016/j. immuni.2009.06.020

24. Xie MH, Aggarwal S, Ho WH, Foster J, Zhang Z, Stinson J, et al. Interleukin (IL)-22, a novel human cytokine that signals through the interferon receptor-related proteins CRF2-4 and IL-22R. J Biol Chem (2000) 275:31335-9. doi:10.1074/jbc.M005304200

25. Dumoutier L, Leemans C, Lejeune D, Kotenko SV, Renauld JC. Cutting edge: STAT activation By IL-19, IL-20 and mda-7 through IL-20 receptor complexes of two types. JImmunol (2001) 167:3545-9. doi:10.4049/ jimmunol.167.7.3545
26. Wang M, Tan Z, Zhang R, Kotenko SV, Liang P. Interleukin 24 (MDA-7/ MOB-5) signals through two heterodimeric receptors, IL-22R1/IL-20R2 and IL-20R1/IL-20R2. J Biol Chem (2002) 277:7341-7. doi:10.1074/jbc. M106043200

27. Wolk K, Kunz S, Witte E, Friedrich M, Asadullah K, Sabat R. IL-22 increases the innate immunity of tissues. Immunity (2004) 21:241-54. doi:10.1016/j. immuni.2004.07.007

28. Lejeune D. Interleukin-22 (IL-22) activates the JAK/STAT, ERK, JNK, and p38 MAP kinase pathways in a rat hepatoma cell line. Pathways that are shared with and distinct from IL-10. J Biol Chem (2002) 277:33676-82. doi:10.1074/jbc.M204204200

29. Dumoutier L, Lejeune D, Colau D, Renauld JC. Cloning and characterization of IL-22 binding protein, a natural antagonist of IL-10-related T cell-derived inducible factor/IL-22. J Immunol (2001) 166:7090-5. doi:10.4049/ jimmunol.166.12.7090

30. Kotenko SV, Izotova LS, Mirochnitchenko OV, Esterova E, Dickensheets H, Donnelly RP, et al. Identification, cloning, and characterization of a novel soluble receptor that binds IL-22 and neutralizes its activity. JImmunol (2001) 166:7096-103. doi:10.4049/jimmunol.166.12.7096

31. Xu W, Presnell SR, Parrish-Novak J, Kindsvogel W, Jaspers S, Chen Z, et al. A soluble class II cytokine receptor, IL-22RA2, is a naturally occurring IL-22 antagonist. Proc Natl Acad Sci U S A (2001) 98:9511-6. doi:10.1073/ pnas. 171303198

32. Martin JCG, Bériou G, Heslan M, Chauvin C, Utriainen L, Aumeunier A, et al. Interleukin-22 binding protein (IL-22BP) is constitutively expressed by a subset of conventional dendritic cells and is strongly induced by retinoic acid. Mucosal Immunol (2014) 7:101-13. doi:10.1038/mi.2013.28

33. Martin JC, Bériou G, Heslan M, Bossard C, Jarry A, Abidi A, et al. IL-22BP is produced by eosinophils in human gut and blocks IL-22 protective actions during colitis. Mucosal Immunol (2016) 9:539-49. doi:10.1038/mi.2015.83

34. Huber S, Gagliani N, Zenewicz LA, Huber FJ, Bosurgi L, Hu B, et al. IL-22BP is regulated by the inflammasome and modulates tumorigenesis in the intestine. Nature (2012) 491:259-63. doi:10.1038/nature11535

35. Sugimoto K, Ogawa A, Mizoguchi E, Shimomura Y, Andoh A, Bhan AK, et al. IL-22 ameliorates intestinal inflammation in a mouse model of ulcerative colitis. J Clin Invest (2008) 118:534-44. doi:10.1172/JCI33194

36. Pickert G, Neufert C, Leppkes M, Zheng Y, Wittkopf N, Warntjen M, et al. STAT3 links IL-22 signaling in intestinal epithelial cells to mucosal wound healing. J Exp Med (2009) 206:1465-72. doi:10.1084/jem.20082683

37. Radaeva S, Sun R, Pan HN, Hong F, Gao B. Interleukin 22 (IL-22) plays a protective role in T cell-mediated murine hepatitis: IL-22 is a survival factor for hepatocytes via STAT3 activation. Hepatology (2004) 39:1332-42. doi:10.1002/hep.20184

38. Zenewicz LA, Yancopoulos GD, Valenzuela DM, Murphy AJ, Karow M, Flavell RA. Interleukin-22 but not interleukin-17 provides protection to hepatocytes during acute liver inflammation. Immunity (2007) 27:647-59. doi:10.1016/j.immuni.2007.07.023

39. Simonian PL, Wehrmann F, Roark CL, Born WK, O'Brien RL, Fontenot AP. $\gamma \delta$ T cells protect against lung fibrosis via IL-22. J Exp Med (2010) 207:223953. doi:10.1084/jem.20100061

40. Sa SM, Valdez PA, Wu J, Jung K, Zhong F, Hall L, et al. The effects of IL-20 subfamily cytokines on reconstituted human epidermis suggest potential roles in cutaneous innate defense and pathogenic adaptive immunity in psoriasis. JImmunol (2007) 178:2229-40. doi:10.4049/ jimmunol.178.4.2229

41. Wolk K, Haugen HS, Xu W, Witte E, Waggie K, Anderson M, et al. IL-22 and IL-20 are key mediators of the epidermal alterations in psoriasis while IL-17 and IFN- $\gamma$ are not. J Mol Med (2009) 87:523-36. doi:10.1007/ s00109-009-0457-0

42. Wolk K, Witte E, Hoffmann U, Doecke WDD, Endesfelder S, Asadullah K, et al. IL-22 induces lipopolysaccharide-binding protein in hepatocytes: a potential systemic role of IL-22 in Crohn's disease. JImmunol (2007) 178:5973-81. doi:10.4049/jimmunol.178.9.5973

43. Ikeuchi H, Kuroiwa T, Hiramatsu N, Kaneko Y, Hiromura K, Ueki K, et al. Expression of interleukin-22 in rheumatoid arthritis: potential role as a proinflammatory cytokine. Arthritis Rheum (2005) 52:1037-46. doi:10.1002/ art.20965 
44. Geboes L, Dumoutier L, Kelchtermans H, Schurgers E, Mitera T, Renauld JC, et al. Proinflammatory role of the Th17 cytokine interleukin-22 in collagen-induced arthritis in C57BL/6 mice. Arthritis Rheum (2009) 60:390-5. doi:10.1002/art.24220

45. Fukui H, Zhang X, Sun C, Hara K, Kikuchi S, Yamasaki T, et al. IL-22 produced by cancer-associated fibroblasts promotes gastric cancer cell invasion via STAT3 and ERK signaling. Br J Cancer (2014) 111:763-71. doi:10.1038/ bjc.2014.336

46. Jiang R, Tan Z, Deng L, Chen Y, Xia Y, Gao Y, et al. Interleukin-22 promotes human hepatocellular carcinoma by activation of STAT3. Hepatology (2011) 54:900-9. doi:10.1002/hep.24486

47. Jiang R, Wang H, Deng L, Hou J, Shi R, Yao M, et al. IL-22 is related to development of human colon cancer by activation of STAT3. BMC Cancer (2013) 13:59. doi:10.1186/1471-2407-13-59

48. Zhang W, Chen Y, Wei H, Zheng C, Sun R, Zhang J, et al. Antiapoptotic activity of autocrine interleukin-22 and therapeutic effects of interleukin-22-small interfering RNA on human lung cancer xenografts. Clin Cancer Res (2008) 14:6432-9. doi:10.1158/1078-0432.CCR-07-4401

49. Wen Z, Liao Q, Zhao J, Hu Y, You L, Lu Z, et al. High expression of interleukin-22 and its receptor predicts poor prognosis in pancreatic ductal adenocarcinoma. Ann Surg Oncol (2014) 21:125-32. doi:10.1245/s10434-013-3322-x

50. Petanidis S, Anestakis D, Argyraki M, Hadzopoulou-Cladaras M, Salifoglou A. Differential expression of IL-17, 22 and 23 in the progression of colorectal cancer in patients with K-ras mutation: ras signal inhibition and crosstalk with GM-CSF and IFN- $\gamma$. PLoS One (2013) 8:e73616. doi:10.1371/journal. pone. 0073616

51. Niccolai E, Taddei A, Ricci F, Rolla S, D'Elios MM, Benagiano M, et al. Intra-tumoral IFN- $\gamma$-producing Th2 cells correlate with TNM staging and the worst outcomes in pancreatic cancer. Clin Sci (2016) 130:247-58. doi:10.1042/CS20150437

52. Kirchberger S, Royston DJ, Boulard O, Thornton E, Franchini F, Szabady RL, et al. Innate lymphoid cells sustain colon cancer through production of interleukin-22 in a mouse model. J Exp Med (2013) 210:917-31. doi:10.1084/ jem.20122308

53. Kryczek I, Lin Y, Nagarsheth N, Peng D, Zhao L, Zhao E, et al. IL-22+CD4+ $\mathrm{T}$ cells promote colorectal cancer stemness via STAT3 transcription factor activation and induction of the methyltransferase DOT1L. Immunity (2014) 40:772-84. doi:10.1016/j.immuni.2014.03.010

54. Wu T, Wang Z, Liu Y, Mei Z, Wang G, Liang Z, et al. Interleukin 22 protects colorectal cancer cells from chemotherapy by activating the STAT3 pathway and inducing autocrine expression of interleukin 8. Clin Immunol (2014) 154:116-26. doi:10.1016/j.clim.2014.07.005

55. Aujla SJ, Chan YR, Zheng M, Fei M, Askew DJ, Pociask DA, et al. IL-22 mediates mucosal host defense against Gram-negative bacterial pneumonia. Nat Med (2008) 14:275-81. doi:10.1038/nm1710

56. Sabat R, Ouyang W, Wolk K. Therapeutic opportunities of the IL-22-IL-22R1 system. Nat Rev Drug Discov (2014) 13:21-38. doi:10.1038/nrd4176

57. Satoh-Takayama N, Vosshenrich CAJ, Lesjean-Pottier S, Sawa S, Lochner M, Rattis F, et al. Microbial flora drives interleukin 22 production in intestinal $\mathrm{NKp} 46+$ cells that provide innate mucosal immune defense. Immunity (2008) 29:958-70. doi:10.1016/j.immuni.2008.11.001

58. Zelante T, Iannitti R, Cunha C, DeLuca A, Giovannini G, Pieraccini G, et al. Tryptophan catabolites from microbiota engage aryl hydrocarbon receptor and balance mucosal reactivity via interleukin-22. Immunity (2013) 39:372-85. doi:10.1016/j.immuni.2013.08.003

59. Sonnenberg GF, Monticelli LA, Alenghat T, Fung TC, Hutnick NA, Kunisawa J, et al. Innate lymphoid cells promote anatomical containment of lymphoid-resident commensal bacteria. Science (2012) 336:1321-5. doi:10.1126/science. 1222551

60. Goto Y, Obata T, Kunisawa J, Sato S, Ivanov II, Lamichhane A, et al. Innate lymphoid cells regulate intestinal epithelial cell glycosylation. Science (2014) 345:1254009. doi:10.1126/science.1254009

61. Pham TA, Clare S, Goulding D, Arasteh JM, Stares MD, Browne HP, et al. Epithelial IL-22RA1-mediated fucosylation promotes intestinal colonization resistance to an opportunistic pathogen. Cell Host Microbe (2014) 16:504-16. doi:10.1016/j.chom.2014.08.017

62. Pickard JM, Maurice CF, Kinnebrew MA, Abt MC, Schenten D, Golovkina TV, et al. Rapid fucosylation of intestinal epithelium sustains host-commensal symbiosis in sickness. Nature (2014) 514:638-41. doi:10.1038/nature13823
63. Hurd EA, Domino SE. Increased susceptibility of secretor factor gene Fut2-null mice to experimental vaginal candidiasis. Infect Immun (2004) 72:4279-81. doi:10.1128/IAI.72.7.4279-4281.2004

64. Behnsen J, Jellbauer S, Wong CP, Edwards RA, George MD, Ouyang W, et al. The cytokine IL-22 Promotes pathogen colonization by suppressing related commensal bacteria. Immunity (2014) 40:262-73. doi:10.1016/j. immuni.2014.01.003

65. Liu Y, Yang B, Zhou M, Li L, Zhou H, Zhang J, et al. Memory IL-22-producing CD4+ T cells specific for Candida albicans are present in humans. Eur J Immunol (2009) 39:1472-9. doi:10.1002/eji.200838811

66. De Luca A, Zelante T, D’Angelo C, Zagarella S, Fallarino F, Spreca A, et al. IL-22 defines a novel immune pathway of antifungal resistance. Mucosal Immunol (2010) 3:361-73. doi:10.1038/mi.2010.22

67. Gessner MA, Werner JL, Lilly LM, Nelson MP, Metz AE, Dunaway CW, et al. Dectin-1-dependent interleukin-22 contributes to early innate lung defense against Aspergillus fumigatus. Infect Immun (2012) 80:410-7. doi:10.1128/ IAI.05939-11

68. Bao W, Jin L, Jing Fu H, Nian Shen Y, Xia Lu G, Mei H, et al. Interleukin-22 mediates early host defense against Rhizomucor pusilluscan pathogens. PLoS One (2013) 8:e65065. doi:10.1371/journal.pone.0065065

69. Ahlfors H, Morrison PJ, Duarte JH, Li Y, Biro J, Tolaini M, et al. IL-22 fate reporter reveals origin and control of IL-22 production in homeostasis and infection. J Immunol (2014) 193:4602-13. doi:10.4049/jimmunol.1401244

70. Shen W, Hixon JA, McLean MH, Li WQ, Durum SK. IL-22-expressing murine lymphocytes display plasticity and pathogenicity in reporter mice. Front Immunol (2016) 6:662. doi:10.3389/fimmu.2015.00662

71. Guo H, Topham DJ. Interleukin-22 (IL-22) production by pulmonary natural killer cells and the potential role of IL-22 during primary influenza virus infection. J Virol (2010) 84:7750-9. doi:10.1128/JVI.00187-10

72. Siegemund S, Schutze N, Schulz S, Wolk K, Nasilowska K, Straubinger RK, et al. Differential IL-23 requirement for IL-22 and IL-17A production during innate immunity against Salmonella enterica serovar Enteritidis. Int Immunol (2009) 21:555-65. doi:10.1093/intimm/dxp025

73. Paget C, Ivanov S, Fontaine J, Renneson J, Blanc F, Pichavant M, et al. Interleukin-22 Is produced by invariant natural killer $\mathrm{T}$ lymphocytes during influenza A virus infection: potential role in protection against lung epithelial damages. J Biol Chem (2012) 287:8816-29. doi:10.1074/jbc. M111.304758

74. Stacey MA, Marsden M, Pham N TA, Clare S, Dolton G, Stack G, et al. Neutrophils recruited by IL-22 in peripheral tissues function as TRAILdependent antiviral effectors against MCMV. Cell Host Microbe (2014) 15:471-83. doi:10.1016/j.chom.2014.03.003

75. Bukowski JF, Woda BA, Habu S, Okumura K, Welsh RM. Natural killer cell depletion enhances virus synthesis and virus-induced hepatitis in vivo. J Immunol (1983) 131:1531-8.

76. Stacey MA, Marsden M, Wang ECY, Wilkinson GWG, Humphreys IR. IL-10 restricts activation-induced death of NK cells during acute murine cytomegalovirus infection. J Immunol (2011) 187:2944-52. doi:10.4049/ jimmunol.1101021

77. Zhao J, Zhang Z, Luan Y, Zou Z, Sun Y, Li Y, et al. Pathological functions of interleukin-22 in chronic liver inflammation and fibrosis with hepatitis $B$ virus infection by promoting Thelper 17 cell recruitment. Hepatology (2014) 59:1331-42. doi:10.1002/hep.26916

78. Brown MG, Dokun AO, Heusel JW, Smith HR, Beckman DL, Blattenberger EA, et al. Vital involvement of a natural killer cell activation receptor in resistance to viral infection. Science (2001) 292:934-7. doi:10.1126/science. 1060042

79. Missé D, Yssel H, Trabattoni D, Oblet C, Lo Caputo S, Mazzotta F, et al. IL-22 participates in an innate anti-HIV-1 host-resistance network through acute-phase protein induction. J Immunol (2007) 178:407-15. doi:10.4049/ jimmunol.178.1.407

80. Oliveira LM, Lima JF, Cervantes CA, Casseb JS, Mendonça M, Duarte AJ, et al. Increased frequency of circulating Tc22/Th22 cells and polyfunctional CD38(-) T cells in HIV-exposed uninfected subjects. Sci Rep (2015) 5:13883. doi:10.1038/srep13883

81. Billerbeck E, Kang YH, Walker L, Lockstone H, Grafmueller S, Fleming V, et al. Analysis of CD161 expression on human CD8+ T cells defines a distinct functional subset with tissue-homing properties. Proc Natl Acad Sci U S A (2010) 107:3006-11. doi:10.1073/pnas.0914839107 
82. Kang YH, Seigel B, Bengsch B, Fleming VM, Billerbeck E, Simmons R, et al. CD161+CD4+ $\mathrm{T}$ cells are enriched in the liver during chronic hepatitis and associated with co-secretion of IL-22 and IFN- $\gamma$. Front Immunol (2012) 3:1-11. doi:10.3389/fimmu.2012.00346

83. Zhang B, Chassaing B, Shi Z, Uchiyama R, Zhang Z, Denning TL, et al. Viral infection. Prevention and cure of rotavirus infection via TLR5/ NLRC4-mediated production of IL-22 and IL-18. Science (2014) 346:861-5. doi:10.1126/science.1256999

84. Hernández PP, Mahlakõiv T, Yang I, Schwierzeck V, Nguyen N, Guendel F, et al. Interferon- $\lambda$ and interleukin 22 act synergistically for the induction of interferon-stimulated genes and control of rotavirus infection. Nat Immunol (2015) 16:698-707. doi:10.1038/ni.3180

85. Sonnenberg GF, Fouser LA, Artis D. Border patrol: regulation of immunity, inflammation and tissue homeostasis at barrier surfaces by IL-22. Nat Immunol (2011) 12:383-90. doi:10.1038/ni.2025

86. Barone F, Nayar S, Campos J, Cloake T, Withers DR, Toellner KM, et al. IL-22 regulates lymphoid chemokine production and assembly of tertiary lymphoid organs. Proc Natl Acad Sci U S A (2015) 112:11024-9. doi:10.1073/ pnas. 1503315112

87. Arias JF, Nishihara R, Bala M, Ikuta K. High systemic levels of interleukin-10, interleukin-22 and C-reactive protein in Indian patients are associated with low in vitro replication of HIV-1 subtype C viruses. Retrovirology (2010) 7:15. doi:10.1186/1742-4690-7-15

88. Kim CJ, Nazli A, Rojas OL, Chege D, Alidina Z, Huibner S, et al. A role for mucosal IL-22 production and Th22 cells in HIV-associated mucosal immunopathogenesis. Mucosal Immunol (2012) 5:670-80. doi:10.1038/mi.2012.72

89. Fernandes SM, Pires AR, Ferreira C, Foxall RB, Rino J, Santos C, et al. Enteric mucosa integrity in the presence of a preserved innate interleukin $22 \mathrm{com}$ partment in HIV type 1-treated individuals. J Infect Dis (2014) 210:630-40. doi:10.1093/infdis/jiu126

90. Pellegrini M, Calzascia T, Toe JG, Preston SP, Lin AE, Elford AR, et al. IL-7 engages multiple mechanisms to overcome chronic viral infection and limit organ pathology. Cell (2011) 144:601-13. doi:10.1016/j.cell.2011.01.011

91. Feng D, Kong X, Weng H, Park O, Wang H, Dooley S, et al. Interleukin-22 promotes proliferation of liver stem/progenitor cells in mice and patients with chronic hepatitis B virus infection. Gastroenterology (2012) 143:188.e-98.e. doi:10.1053/j.gastro.2012.03.044

92. Guabiraba R, Besnard A-G, Marques RE, Maillet I, Fagundes CT, Conceição TM, et al. IL-22 modulates IL-17A production and controls inflammation and tissue damage in experimental dengue infection. Eur J Immunol (2013) 43:1529-44. doi:10.1002/eji.201243229

93. Kumar P, Thakar MS, Ouyang W, Malarkannan S. IL-22 from conventional NK cells is epithelial regenerative and inflammation protective during influenza infection. Mucosal Immunol (2012) 6:69-82. doi:10.1038/ mi.2012.49

94. Ivanov S, Renneson J, Fontaine J, Barthelemy A, Paget C, Fernandez EM, et al. Interleukin-22 reduces lung inflammation during influenza A virus infection and protects against secondary bacterial infection. J Virol (2013) 87:6911-24. doi:10.1128/JVI.02943-12
95. Pociask DA, Scheller EV, Mandalapu S, McHugh KJ, Enelow RI, Fattman CL, et al. IL-22 is essential for lung epithelial repair following influenza infection. Am J Pathol (2013) 182:1286-96. doi:10.1016/j.ajpath.2012.12.007

96. Guo Y, Wu W, Cen Z, Li X, Kong Q, Zhou Q. IL-22-producing Th22 cells play a protective role in CVB3-induced chronic myocarditis and dilated cardiomyopathy by inhibiting myocardial fibrosis. Virol J (2014) 11:230. doi:10.1186/s12985-014-0230-Z

97. Wang P, Bai F, Zenewicz LA, Dai J, Gate D, Cheng G, et al. IL-22 signaling contributes to West Nile encephalitis pathogenesis. PLoS One (2012) 7:e44153. doi:10.1371/journal.pone.0044153

98. Zhang Y, Cobleigh MA, Lian JQ, Huang CX, Booth CJ, Bai XF, et al. A proinflammatory role for interleukin-22 in the immune response to hepatitis B virus. Gastroenterology (2011) 141:1897-906. doi:10.1053/j. gastro.2011.06.051

99. Parkin DM. The global health burden of infection-associated cancers in the year 2002. Int J Cancer (2006) 118:3030-44. doi:10.1002/ijc.21731

100. Waidmann O, Kronenberger B, Scheiermann P, Köberle V, Mühl H, Piiper A. Interleukin-22 serum levels are a negative prognostic indicator in patients with hepatocellular carcinoma. Hepatology (2014) 59:1207. doi:10.1002/ hep. 26528

101. Jiang R, Zhang C, Xia Y, Qian X, Wang X, Sun B. Reply: to PMID 21674558. Hepatology (2014) 59:1208. doi:10.1002/hep.26613

102. Kulcsar KA, Baxter VK, Greene IP, Griffin DE. Interleukin 10 modulation of pathogenic Th17 cells during fatal alphavirus encephalomyelitis. Proc Natl Acad Sci U S A (2014) 111:16053-8. doi:10.1073/pnas.1418966111

103. Liang SC, Tan X-Y, Luxenberg DP, Karim R, Dunussi-Joannopoulos K, Collins M, et al. Interleukin (IL)-22 and IL-17 are coexpressed by Th17 cells and cooperatively enhance expression of antimicrobial peptides. J Exp Med (2006) 203:2271-9. doi:10.1084/jem.20061308

104. Zheng Y, Valdez PA, Danilenko DM, Hu Y, Sa SM, Gong Q, et al. Interleukin-22 mediates early host defense against attaching and effacing bacterial pathogens. Nat Med (2008) 14:282-9. doi:10.1038/nm1720

105. Ichinohe T, Pang IK, Kumamoto Y, Peaper DR, Ho JH, Murray TS, et al. Microbiota regulates immune defense against respiratory tract influenza A virus infection. Proc Natl Acad Sci U S A (2011) 108:5354-9. doi:10.1073/ pnas. 1019378108

106. McCullers JA. The co-pathogenesis of influenza viruses with bacteria in the lung. Nat Rev Microbiol (2014) 12:252-62. doi:10.1038/nrmicro3231

Conflict of Interest Statement: The authors declare that the research was conducted in the absence of any commercial or financial relationships that could be construed as a potential conflict of interest.

Copyright (c) 2016 Gimeno Brias, Stack, Stacey, Redwood and Humphreys. This is an open-access article distributed under the terms of the Creative Commons Attribution License (CC BY). The use, distribution or reproduction in other forums is permitted, provided the original author(s) or licensor are credited and that the original publication in this journal is cited, in accordance with accepted academic practice. No use, distribution or reproduction is permitted which does not comply with these terms. 